\title{
Revitalização da Praça Gadioli: Espaço para o Lazer e a Percepção de Segurança pelos Usuários e Moradores da Região
}

\section{Adriana Gimenes Gonçalves, Silvia C. F. Amaral.}

\section{Resumo}

Esta pesquisa teve por objetivo investigar as mudanças que ocorreram no distrito de Barão Geraldo, depois do processo de revitalização da Praça Mário Gadioli principalmente em relação à percepção de segurança dos usuários da praça e dos moradores da região. Na elaboração deste estudo surgiram alguns questionamentos: como a revitalização e utilização de equipamentos de lazer pode influenciar na percepção de segurança dos moradores do entorno do equipamento e dos usuários de um determinado equipamento público de lazer? A pesquisa de caráter qualitativo foi baseada nas respostas de diferentes questionários que foram entregues, um para os usuários da praça e outro para os moradores que vivem em volta desta. Também foram realizadas observações na praça em diferentes períodos do dia e em diferentes dias da semana. Após a aplicação do questionário constatou-se que para a maioria dos usuários a revitalização teve grande influência na sensação de segurança. Entre os argumentos citados estavam a aproximação da população local, o aumento da circulação de pessoas e melhora na iluminação. Assim, ao final do estudo buscamos identificar, quais atividades de lazer são realizadas, quais mudanças ocorreram na região após o projeto de urbanização e a percepção dos moradores e usuários após a revitalização da praça.

Palavras-chave:

Lazer, espaço público,segurança.

\section{Introdução}

Localizada na região central de Barão Geraldo, a Praça Mário Gadioli recentemente passou por um processo de revitalização. Anteriormente a esse processo, a praça apresentava somente duas quadras sem manutenção. O resto do espaço apresentava uma condição de manutenção precária com muito mato e entulhos, se tornando um depósito de lixo. Hoje a praça é composta por uma quadra poliesportiva, pista de skate, campo de futebol de areia, parque para crianças e academia ao ar livre.

Como objetivo, pretendemos analisar as mudanças causadas pela revitalização de um equipamento de lazer e a percepção de segurança dos moradores da região e usuários deste equipamento e elencar quais atividades de lazer são realizadas neste espaço.

\section{Resultados e Discussão}

Para a elaboração da pesquisa, foi entregue um questionário para os usuários da praça e um outro para os moradores que circundam a praça. Além disso foi realizado observações em diferentes períodos do dia e diferentes dias da semana.

Em relação a revitalização e a sensação de segurança, $76 \%$ dos participantes responderam que a revitalização influenciou na sensação de segurança, 13\% responderam que influenciou pouco, $3,3 \%$ que não influenciou e 6,6\% não opinaram.

Os motivos mais citados para a melhora na sensação de segurança foram: aumento no fluxo de pessoas, aproximação da população local e melhora na iluminação.

Estes dados corroboram com os estudos de Jacobs (2013). Para a autora, uma rua movimentada tem tendência a ser uma rua mais segura. Com uma rua mais atrativa, teremos mais "olhos" a vigiando e por isso há uma maior sensação de segurança

Sobre lazer e Gênero, dos participantes, $70 \%$ eram homens e $30 \%$ mulheres. Destas, 36\% das mulheres participantes não realizavam atividades na praça, apenas acompanhavam o filho. Com os resultados podemos notar também uma diferença nas atividades entre homens e mulheres.

Dados colaboram com os estudos de Goellner et al (2010), onde mulheres realizavam suas atividades de lazer junto com a própria família ou dentro do ambiente doméstico enquanto que os homens preferem realizar ao ar livre e fora de casa.

As atividades de lazer observadas pela pesquisadora foram: caminhada, corrida, atividades na academia ao ar livre, passear com o cachorro, andar de skate, jogar futebol de areia, jogar futsal, vôlei de areia, vôlei, andar de bicicleta, crianças brincando no parquinho, andar de patins, brincar com os filhos, piquenique, dança e roda de capoeira.

Os participantes relataram as seguintes atividades: Torcida, descansar vendo as crianças brincarem, caminhada, passear com o cachorro, trazer o filho para brincar, andar de skate, passear, futebol, alongamentos e exercícios físicos, academia, andar de patins, corrida.

\section{Conclusões}

Com os resultados constatamos que que mais pessoas passaram a utilizar um espaço que antes era utilizado por um grupo reduzido. Articulação de pessoas aumentou, proporcionando que essas praticassem as mais variadas atividades de lazer e práticas vinculadas à cultura corporal em um espaço público e gratuito.

Apesar de ser necessário mais estudos, observamos resultados positivos que a revitalização trouxe para as pessoas e para a região em termos de sensação de segurança e acesso ao lazer.

\section{Agradecimentos}

Ao Grupo de Estudos GEP'L, Silvia C. F. Amaral e a Instituição SAE-Unicamp.

\footnotetext{
${ }^{1}$ Goellner, S. V., Voltre, S. J., Mourão, L., Figueira, M. L. M,. Lazer e Gênero nos Programas de Esporte e Lazer das Cidades. Licere. 2010, v.13, n.12, p.120.

2 Jacobs, J. Muerte y Vida de Las Grandes Ciudades. Capitán Swing Libros. 2013
} 